\title{
Efektifitas The 6 Steps Reasoning Diagnosis Method dan Intan,s Clinical Reasoning Model (ICRM) dalam Penentuan Standar Asuhan Keperawatan (SAK) pada Setting Keperawatan Maternitas
}

\author{
Lisa Suarni \\ Prodi Keperawatan Kotabumi, Politeknik Kesehatan Tanjungkarang \\ Email: lisakausar@yahoo.co.id
}

\begin{abstract}
Effectivity of The 6 Steps Reesoning Diagnosis Method and Intan's Clinical Reasoning Model (ICRM) in Nursing Care Standard Determination on Maternity Nursing Setting. Nurses doing their task and function need to have a standard to be able to be controlled, to be paid, to be taught, to be applied, and to be a hospital legal decision, thus the arrangement of the standard should be adjusted according to patient and hospital condition. The nursing care standard arrangement with ISDA and ICRM approach will be tested in this study. This study aimed to identify nursing diagnosis with The 6 steps of diagnostic reasoning method, to identify NIC, NOC and to test effectivity of the arranged nursing care standard. Methods: Stage I: identify nursing diagnosis in the six most prevalent cases patients in the ward using the six steps. Stage II: according to the nursing diagnosis that has been identified researcher decides NIC choice using Intan's Clinical Reasoning Model (ICRM), then selected NOC and NIC be tested its effectivity using t-test analysis. Stage I result shows that using the 6 steps of diagnostic reasoning method in section caesarean patients researcher identifies 13 diagnoses, 9 diagnoses in spontaneous birthing, 7 diagnoses in antepartum hemorrhage, 2 diagnoses in postpartum hemorrhage, 7 diagnoses in preeclampsia/ eclampsia, 4 diagnoses in early amniotic membrane rupture, $36(94.4 \%)$ NOCs identification and 28 (93.3\%) NICs are applicative. Meanwhile, on stage II which is to test the nursing care standard effectivity, 16 nursing care standard are effective with $\mathrm{p}$-value $<0.05$.
\end{abstract}

Keywords: Diagnoses, NOC, NIC, Maternity

\begin{abstract}
Abstrak: Efektifitas The 6 Steps Reasoning Diagnosis Method dan Intan,s Clinical Reasoning Model (ICRM) dalam Penentuan Standar Asuhan Keperawatan (SAK) pada Setting Keperawatan Maternitas. Perawat dalam melaksanakan tugas dan fungsinya perlu memiliki suatu standar agar dapat dikontrol, dibiayai, diajarkan, dapat diaplikasikan dan menjadi kebijakan rumah sakit, oleh karena itu penyusunan standar harus disesuaikan dengan kondisi pasien dan Rumah Sakit. Penyusunan Standar Asuhan Keperawatan (SAK) dengan pendekatan ISDA dan ICRM akan diujicobakan dalam penelitian ini. Penelitian ini bertujuan Untuk mengidentifikasi diagnosa keperawatan dengan pendekatan The 6 steps of diagnostic reasoning method, Mengidentifikasi NIC, NOC dan menguji efektifitas SAK yang disusun. Methode yang digunakan: Tahap I: Mengidentifikasi diagnosa keperawatan pada klien kasus 6 terbesar di Ruangan dengan menggunakan 6 steps.Tahap II : Berdasarkan diagnosa keperawatan yang teridentifikasi ditentukan pilihan NIC dengan menggunakan Intan's Clinical Reasoning Model (ICRM, selanjutnya NOC dan NIC terpilih dinilai efektifitasnya dengan menggunakan analisis $t$ test. Hasil penelitian tahap I menunjukan bahwa dengan menggunakan The 6 steps of diagnostic reasoning method pada klien seksio caessarea teridentifikasi 13 diagnosa, persalinan spontan 9 diagnosa, perdarahan antepartum 7 diagnosa, perdarahan post partum 2 diagnosa, preeklampsi/eklampsi 7 diagnosa, ketuban pecah dini 4 diagnosa, Identifikasi NOC $36(94,4 \%)$ dan NIC : 28 (93,3\%) aplikatif. Sedangkan untuk penelitian tahap II untuk menguji efektifitas SAK, 16 SAK dinyatakan efektif dengan nilai p-value $<0,05$.
\end{abstract}

Keywords: Diagnosis, NOC, NIC, Maternitas

Sesuai dengan Peraturan Presiden Nomor 77 tahun 2015 tentang Pedoman Organisasi Rumah Sakit, Unsur Keperawatan merupakan salah unsur yang harus ada dalam organisasi rumah sakit. Unsur keperawatan bertugas melaksanakan pelayanan keperawatan dengan fungsi menyusun rencana pemberian pelayanan keperawatan dan berkoordinasi dalam pelaksanaan keperawatan (Shelvie, R. A.H., 2012)

Tugas dan fungsi tersebut hanya bisa dijalankan oleh seorang perawat profesional, dimana dalam menjalankan tugasnya menggunakan metode berfikir kritis dengan 
proses keperawatan (nursing process) sebagai kerangka pikir dan kerangka kerja dalam merawat pasien. Keperawatan sebagai proses, diperkenalkan sejak tahun 1995 oleh Hall dan pada tahun 2004 proses keperawatan (nursing process) ditetapkan sebagai series of steps oleh ANA (American Nursing Association) (Wilkinson, 2007), yang terdiri dari assesment (pengkajian), diagnosis (penetapan diagnosa), planning outcomes (perencanaan hasil), planning intervention (perencanaan intervensi), implementation (implementasi) dan evaluation (evaluasi) (Perry and Potter, 2016).

Berbagai persoalan yang muncul dalam pelaksanaan fungsi dan tugas perawat tersebut antara lain: pemahaman perawat terhadap tugas dan fungsinya tidak sama ditambah lagi dengan kemampuan perawat dalam memahami proses keperawatan masih kurang, pemahaman dan persepsi tugas dan fungsi perawat oleh tenaga kesehatan lain tidak sama (masih ada persepsi bahwa perawat hanya menuunggu instruksi dari dokter), belum ada standar yang disepakati bersama oleh semua tenaga kesehatan (-perawat-dokter-ahli gizi-apoteker, analis). (Wawancara dengan Perawat di klinik dan Rumah Sakit di Lampung pada Workshop 19-20 Desember 2015).

Sangat penting bagi seorang perawat memahami tugas dan fungsinya, dan tugas dan fungsi tersebut hanya bisa dilaksanakan dengan cara memahami proses keperawatan, persoalannya pemahaman tersebut juga sangat dipengaruhi oleh tingkat pendidikan perawat, sementara di berbagai rumah sakit pendidikan perawatan masih sangat bervariasi, dari yang berpendidikan SPK, DIII Keperawatan dan sebagian kecil S1 keperawatan, dengan pengalaman bekerja di klinik/rumah sakit sangat bervariasi (Hasil Survey di beberapa Rumah Sakit di Lampung Utara).

Asuhan keperawatan yang diberikan oleh setiap perawat harus terstandar, dengan standar ini menjadikan asuhan keperawatan yang diberikan dapat terukur, jika kita tidak bisa memberikan standar/ label, kita tidak bisa mengontrolnya, membiayainya, mengajarkannya, atau mengusulkan untuk menjadi kebijakan publik (Clark and Lang, 1992), sehingga penilaian kinerja terhadap perawat juga dapat dilaksanakan, kinerja perawat profesional dapat memberikan dampak pada pelayanan di rumah sakit, seperti yang diketahui bahwa hampir 24 jam waktu pasien adalah bersama perawat, ini artinya perawat memiliki kontribusi yang besar terhadap pelayanan rumah sakit pada umumnya.

Persatuan Perawat Nasional Indonesis
(PPNI), telah menyusun standar asuhan keperawatan yang didefinisikan sebagai pernyataan kualitas yang diinginkan dan dapat dinilai pemberian asuhan keperawatan terhadap pasien/klien, namun standar tersebut belum rinci dan masih membutuhkan pernyataan standar yang operasional setiap tahapannya. Standar asuhan keperawatan suatu institusi pelayanan harus disesuaikan dengan kondisi kesehatan klien, diagnosa atau masalah kesehatan klien, karakteristik klien, apa yang lebih disukai klien, dan potensi untuk penanganan (Moorhead, Johnson \& Maas, 2004).

Faktor yang perlu dipertimbangkan dalam menyeleksi pilihan Nursing Intervention Classification (NIC) adalah hasil yang diinginkan klien, karakter diagnosa keperawatan, Research based on nursing diagnosis - EVIDENCE BASED, kemungkinan bisa dilaksanakan, penerimaan klien dan kemampuan perawat (Bulechek, Butcher \& Dochterman, 2008).

Evidence Based adalah mencari dan menggabungkan sumber-sumber terpercaya dari evidence/pembuktian yang telah dilakukan salah satunya melalui riset, hal ini penting karena ketika sesuatu memiliki resiko, penting mendapatkan informasi yang tidak hanya sekedar OPINI (Brow, 2014). Atas pertimbangan ini dibutuhkan penelitian untuk menentukan standar pengkajian, diagnosa keperawatan, Nursing Outcome Classification (NOC) dan Nursing Intervention Classification (NIC).

Evidence Base yang telah dilakukan oleh Suarni, dkk pada area perioperative mendapatkan hasil bahwa Diagnosa yang ditegakkan oleh perawat lebih sedikit dibanding dengan diagnosa dengan 6 steps, dengan menggunakan The 6 steps method of diagnostic reasoning diagnosa yang ditegakkan lebih beragam, lebih heterogen pada kondisi preoprative sedangkan pada kondisi intra dan Postoperative lebih homogen, lebih komprehensif, membuktikan bahwa pemilihan metode yang tepat dalam setiap proses keperawatan menentukan kualitas standar asuhan yang dibuat (Suarni, Nurjannah, Apriyani, 2015), dan penelitian tahap ke dua dengan avidance base NIC dan NOC yang disusun berdasarkan Intan Clinical Reasoning Method (ICRM) menghasilkan beberapa NIC dan NOC yang aplikatif di area perioperative RSUD Mayjend HM Ryacudu Lampung Utara (Suarni, Apriyani, 2015).

Dalam penentuan diagnosa keperawatan banyak alternatif pendekatan yang dapat digunakan, jenis taxonomi tersebut antara lain : NANDA, OMAHA SYSTEM, ICNP, CCC, dll (Westra, et al, 2008 dalam Nurjannah, 2013), 
namun pada dasarnya semua pendekatan tersebut bersumber dari NANDA, NIC, NOC, dengan bervariasinya pendekatan tersebut membutuhkan jalan tengah agar dapat memahami proses keperawatan dengan sederhana.

Nurjannah (2013), dengan pendekatan 6 steps of diagnostic reasoning method memberikan alternatif pendekatan proses keperawatan yang realistis dan dapat diaplikasikan pada pasien, sesuai dengan hasil penelitian Suarni, Apriyani (2015) terhadap pasien perioperative menggambarkan bahwa standar asuhan yang disusun dengan pendekatan NANDA (The 6 steps of diagnostic reasoning method), NOC dan NIC aplikatif dilaksanakan di RSUD Mayjend HM Ryacudu.

Metode 6 langkah penegakan diagnosa ini telah dipelajari oleh banyak perawat di seluruh Indonesia melalui workshop NANDA, NOC dan NIC, namun sejauh mana metode ini diaplikasikan tatanan (klinik rumah sakit/ puskesmas)?. Beberapa perawat menyatakan ketertarikan menggunakan metode ini namun masih banyak yang bertanya bagaimana menerapkannya pada asuhan keperawatan pada pasien? Survey yang dilakukan pada beberapa rumah sakit di Lampung yang beberapa perawatnya telah mengikuti workshop metode 6 langkah ini menunjukkan belum mengaplikasikannya di tatanan klinik (Pra Survey pada bulan Februari 2016).

Rumah Sakit Mayjend HM Ryacudu Lampung Utara, yang merupakan salah satu rumah sakit terbesar di Lampung Utara, di beberapa ruang rawat, termasuk ruang kebidanan telah memiliki Standar Asuhan Keperawatan (SAK), persoalannya SAK yang disusun sebagian besar tidak dipahami dan tidak dilaksanakan oleh perawat/bidan di ruangan, termasuk juga ruang kebidanan, padahal Standar Asuhan Keperawatan merupakan pedoman bagi perawat dalam melaksanakan pekerjannya (Survey pada RSUD Mayjend HM Ryacudu Lampung utara pada bulan Februari 2016).

\section{METODE}

Penelitian ini adalah penelitian dengan rancangan deskriptif komparatif dan quasi eksperimen, dengan tahapan sebagai berikut:

Tahap I: Mengidentifikasi diagnosa keperawatan pada pasien dengan menggunakan 6 steps.

Tahap II: Berdasarkan diagnosa keperawatan yang teridentifikasi disusun Standar Asuhan Keperawatan (SAK) (NOC dan NIC) dengan menggunakan ICRM.

Tahap III: Setelah menentukan pilihan NOC dan
NIC sebagai Standar Asuhan Keperawatan, selanjutnya diujicobakan pada pasien oleh perawat, dengan terlebih dahulu mensosialisasikan NOC dan NIC tersebut kepada perawat/ bidan di ruangan kebidanan. Efektifitas intervensi dinilai dari dengan perbandingan skor NOC sebelum dan sesudah intervensi.

Populasi dalam penelitian ini adalah seluruh klien yang dirawat di ruang kebidanan. Sesuai dengan rancaangan penelitian yang telah dijelaskan di atas bahwa Penelitian ini terdiri dari 2 tahapan yaitu: tahap I Identifikasi diagnosa, sampel dalam penelitian tahap I adalah sejumlah klien dengan 6 kasus terbesar di Ruangan Kebidanan (berdasarkan prasurvey): Seksio Caessarea (SC), Persalinan normal, Post Partum Haemoraghi (PPH), Ante Partum Haemoragi dengan jumlah masing-masing 10 klien. Tahap II adalah mengujicobakan SAK pada masing-masing SAK yang disusun dicobakan pada 5 klien. Metode sampling: insidental sampling dengan kriteria inklusi bersedia menjadi responden dan menandatangani inform concent.

Pengumpulan data dilakukan 2 tahap, tahap 1 mengumpulkan data berupa data subjektif (diperoleh dengan wawancara/anamnesa) dan data objektif diperoleh dengan teknik observasi dan pemeriksaan fisik dengan panduan format pengumpulan data (terlampir), Penelitian tahap 2 pengumpulan data berupa penilaian skor NOC sebelum dan sesudah intervensi sesuai NIC dengan cara anamnesa, observasi dan pemeriksaan fisik dan pemeriksaan laboratorium.

Pengolahan data penentuan efektifitas SAK, dengan menganalisis skor NOC sebelum dan sesudah dilakukan tindakan sesuai dengan NIC, menggunakan $t$ test.

\section{HASIL}

\section{Diagnosa Nyeri Akut: NIC Manajemen Nyeri dan Pemberian Analgetik}

Tabel 1. Perbedaan Mean Skor NOC: Tingkat Nyeri Sebelum dan Setelah Intervensi

\begin{tabular}{lrrrrr}
\multicolumn{1}{c}{ Variabel } & Mean & SD & SE & $p$-value & $\mathrm{n}$ \\
\hline Tingkat Nyeri & & & & & \\
Sebelum & 44,50 & 14,034 & 4,436 & 0,044 & 10 \\
Sesudah & 43,90 & 17,091 & 5,405 & & \\
\hline
\end{tabular}

Dari tabel 1 di atas dapat dilihat dengan nilai $p$-value $0,044 \quad(<0,05)$ maka dapat disimpulkan bahwa ada perbedaan skor mean Level Nyeri sebelum dengan setelah diintervensi, berarti SAK efektif (NIC: manajemen nyeri dan pemberian analgetik efektif menurunkan 
tingkatan nyeri)

2. NIC Manajemen Konstipasi Terhadap Eliminasi Usus

Tabel 2. Perbedaan Mean Skor NOC: Eliminasi Usus Sebelum dan Setelah Intervensi

\begin{tabular}{lccccc}
\hline \multicolumn{1}{c}{ Variabel } & Mean & SD & SE & $\begin{array}{c}p- \\
\text { value }\end{array}$ & N \\
\hline $\begin{array}{l}\text { Eliminasi Usus } \\
\text { Sebelum }\end{array}$ & 44,70 & 26,154 & 8,270 & 0,018 & 10 \\
Sesudah & 75,10 & 28,773 & 0,099 & & \\
\hline
\end{tabular}

Dari tabel 2 di atas dapat dilihat dengan nilai $p$-value $0,018 \quad(<0,05)$ maka dapat disimpulkan bahwa ada perbedaan skor mean Eliminasi usus sebelum dengan setelah diintervensi, berarti SAK efektif (NIC: manajemen konstipasi efektif memperbaiki eliminasi usus).

\section{NIC Perawatan Post Partum terhadap Status Sirkulasi}

Tabel 3. Perbedaan Mean Skor NOC: Status Sirkulasi Sebelum dan Setelah Intervensi

\begin{tabular}{lrrrrr}
\hline \multicolumn{1}{c}{ Variabel } & Mean & SD & SE & $p$-value & N \\
\hline \multicolumn{2}{l}{ Status Sirkulasi } & & & & \\
Sebelum & 18,80 & 2,168 & 0,970 & 0,49 & 5 \\
Sesudah & 25,60 & 3,782 & 1,691 & & \\
\hline
\end{tabular}

Dari tabel 3 di atas dapat dilihat dengan nilai $p$-value $0,049 \quad(<0,05)$ maka dapat disimpulkan bahwa ada perbedaan skor mean Status sirkulasi sebelum dengan setelah diintervensi, berarti SAK efektif (NIC : Perawatan Perdarahan efektif memperbaiki status sirkulasi)

4. NIC Perawatan Luka Sayatan dan Perawatan Persalinan Seksio terhadap Keparahan Infeksi

Tabel 4. Perbedaan Mean Skor NOC: Keparahan Infeksi Sebelum dan Setelah Intervensi

\begin{tabular}{lrrrrr}
\hline \multicolumn{1}{c}{ Variabel } & Mean & SD & SE & $\begin{array}{c}p- \\
\text { value }\end{array}$ & $\mathrm{N}$ \\
\hline $\begin{array}{l}\text { Keparahan Infeksi } \\
\text { Sebelum }\end{array}$ & 16,60 & 3,921 & 1,240 & 0,006 & 10 \\
Sesudah & 30,00 & 5,099 & 1,612 & & \\
\hline
\end{tabular}

Dari tabel 4 di atas dapat dilihat dengan nilai $p$-value $0,006 \quad(<0,05)$ maka dapat disimpulkan bahwa ada perbedaan skor mean Keparahan infeksi sebelum dengan setelah diintervensi, berarti SAK efektif (NIC: Perawatan
Luka sayatan dan perawatan persalinan seksio memperbaiki Menurunkan keparahan infeksi)

5. NIC Koordinasi Preoperatif terhadap Pemulihan Pasca Bedah: Segera Setelah Operasi

Tabel 5. Perbedaan Mean Skor NOC Pemulihan pasca Bedah: segera setelah operasi Sebelum dan Setelah Intervensi

\begin{tabular}{lccccc}
\hline \multicolumn{1}{c}{ Variabel } & Mean & SD & SE & p-value & n \\
\hline Pemulihan Pasca Bedah & & & & \\
Sebelum & 18,80 & 2,168 & 0,970 & 0,18 & 5 \\
Sesudah & 24,20 & 1,304 & 0,583 & &
\end{tabular}

Dari tabel $5 \mathrm{di}$ atas dapat dilihat dengan nilai $p$-value $0,018 \quad(<0,05)$ maka dapat disimpulkan bahwa ada perbedaan skor mean Pemulihan pasca bedah sebelum dengan setelah diintervensi, berarti SAK efektif (NIC: Koordinase preoperatif memperbaiki pemulihan pasca bedah).

6. NIC Perawatan Tirah Baring terhadap Inisiatif Merubah Posisi Sendiri

Tabel 6. Perbedaan Mean Skor NOC Inisiatif merubah Posisi Tubuh Sendiri Sebelum dan Setelah Intervensi

\begin{tabular}{lccccc}
\hline \multicolumn{1}{c}{ Variabel } & Mean & SD & SE & $p$-value & $\mathrm{n}$ \\
\hline Inisitatif merubah posisi sendiri & & & \\
Sebelum & 20,60 & 2,675 & 0,846 & 0,009 & 10 \\
Sesudah & 35,10 & 6,724 & 6,724 & &
\end{tabular}

Dari tabel 6 di atas dapat dilihat dengan nilai $p$-value $0,009 \quad(<0,05)$ maka dapat disimpulkan bahwa ada perbedaan skor mean inisiatif merubah Posisi tubuh sendiri sebelum dengan setelah diintervensi, berarti SAK efektif (NIC: Perawatan tirah baring meningkatkan inisiatif untuk merubah posisi sendiri)

7. NIC Pengurangan Kecemasan terhadap Tingkat Kecemasan

Tabel 7. Perbedaan Mean Skor NOC: Keparahan Tingkat kecemasan Sebelum dan Setelah Intervensi

\begin{tabular}{|c|c|c|c|c|c|}
\hline Variabel & Mean & SD & SE & $p$-value & $\mathrm{n}$ \\
\hline \multicolumn{6}{|c|}{ Tingkat Kecemasan } \\
\hline Sebelun & 19,00 & 2,106 & 0,667 & 0,031 & 10 \\
\hline Sesudah & 31,20 & 3,393 & 1,073 & & \\
\hline
\end{tabular}

Dari tabel $7 \mathrm{di}$ atas dapat dilihat dengan nilai p-value $0,031(<0,05)$ maka dapat disimpulkan bahwa ada perbedaan skor mean tingkat kecemasan sebelum dengan setelah 
diintervensi, berarti SAK efektif (NIC: pengurangan kecemasan menurunkan tingkat kecemasan).

8. NIC Konseling Laktasi terhadap Keberhasilan Menyusui: Maternal

Tabel 8. Perbedaan Mean Skor NOC Menyusui: Bayi Sebelum dan Setelah Intervensi

\begin{tabular}{llllll}
\hline Variabel & Mean & SD & SE & $\begin{array}{c}p \text { - } \\
\text { value }\end{array}$ & N \\
\cline { 1 - 4 } Keberhasilan menyusui Maternal & & \\
- Sebelum & 19,70 & 2,312 & 0,731 & 0,003 & 10 \\
- Sesudah & 28,70 & 1,889 & 0,597 & & \\
\hline
\end{tabular}

Dari tabel 8 di atas dapat dilihat dengan nilai $p$-value $0,003 \quad(<0,05)$ maka dapat disimpulkan bahwa ada perbedaan skor mean Keberhasilan menyusui Maternal sebelum dengan setelah diintervensi, berarti SAK efektif (NIC: Konseling laktasi meningkatkan keberhasilan menyusui bayi).

9. NIC Pengajaran Perawatan Ibu Post Partum terhadap Pengetahuan Kesehatan Ibu Post Partum

Tabel 9. Perbedaan Mean Skor NOC Pengetahuan Ibu Post Partum Sebelum dan Setelah Intervensi

\begin{tabular}{lllllll}
\hline Variabel & Mean & SD & SE & p-value & N \\
\cline { 1 - 4 } Pengetahuan Kesehatan & ibu Post partum & & \\
- Sebelum & 14,60 & 3,286 & 1,470 & 0,008 & 5 \\
- Sesudah & 27,20 & 3,834 & 1,715 & & \\
\hline
\end{tabular}

Dari tabel 9 di atas dapat dilihat dengan nilai $p$-value $0,008 \quad(<0,05)$ maka dapat disimpulkan bahwa ada perbedaan skor mean Pengetahuan Kesehatan ibu Post partum sebelum dengan setelah diintervensi, berarti SAK efektif (NIC: Pengajaran Perawatan ibu post partum efektif meningkatkan pengetahuan kesehatan ibu post partum).

\section{Pencegahan Perdarahan terhadap Keparahan Kehilangan Darah}

Tabel 10. Perbedaan Mean Skor NOC Keparahan Kehilangan Darah Sebelum dan Setelah Intervensi

\begin{tabular}{lrrrrr}
\hline \multicolumn{1}{c}{ Variabel } & Mean & SD & SE & p-value & N \\
\hline Keparahan kehilangan & darah & & & \\
Sebelum & 10,80 & 5,594 & 1,769 & 0,020 & 10 \\
Sesudah & 70,60 & 17,373 & 5,494 & & \\
\hline
\end{tabular}

Dari tabel 10 di atas dapat dilihat dengan nilai $p$-value $0,020 \quad(<0,05)$ maka dapat disimpulkan bahwa ada perbedaan skor mean Keparahan kehilangan darah sebelum dengan setelah diintervensi, berarti SAK efektif (NIC: Pencegahan perdarahan efektif menurunkan keparahan kehilangan darah).

\section{Peningkatan Kelekatan terhadap Kelekatan Orang Tua-bayi}

Tabel 11.Perbedaan Mean Skor NOC Kelekatan orang tua-Bayi Sebelum dan Setelah Intervensi

\begin{tabular}{lccccc} 
Variabel & Mean & SD & SE & p-value & n \\
\cline { 1 - 5 } Kelekatan orang tua - Bayi & & & \\
- Sebelum & 20,60 & 2,675 & 0,846 & 0,001 & 10 \\
- Sesudah & 35,30 & 6,684 & 2,114 & & \\
\hline
\end{tabular}

Dari tabel di atas dapat dilihat dengan nilai p-value $0,001(<0,05)$ maka dapat disimpulkan bahwa ada perbedaan skor mean Kelekatan orang tua-bayi sebelum dengan setelah diintervensi, berarti SAK efektif (NIC : Peningkatan kelekatan efektif meningkatkan kelekatan orang tua-bayi).

\section{Pencegahan Kejang terhadap Kontrol Kejang Sendiri}

Tabel 12. Perbedaan Mean Skor NOC Kontrol Kejang Sendiri Sebelum dan Setelah Intervensi

\begin{tabular}{lrrrrr}
\hline \multicolumn{1}{c}{ Variabel } & Mean & SD & SE & p-value & $\mathrm{n}$ \\
\hline Kontrol Kejang Sendiri & & & & \\
Sebelum & 7,10 & 2,846 & 0,900 & 0,022 & 10 \\
Sesudah & 14,80 & 2,150 & 0,860 & & \\
\hline
\end{tabular}

Dari tabel 12 di atas dapat dilihat dengan nilai p-value $0,022 \quad(<0,05)$ maka dapat disimpulkan bahwa ada perbedaan skor mean Kontrol kejang sendiri sebelum dengan setelah diintervensi, berarti SAK efektif (NIC: Pencegahan kejang efektif meningkatkan kontrol kejang sendiri).

\section{Pengajaran Proses Penyakit: Hipertensi terhadap Pengetahuan Manajemen Hipertensi}

Tabel 13. Perbedaan Mean Skor NOC Pengetahuan Manajemen Hipertensi Sebelum dan Setelah Intervensi

\begin{tabular}{lccccc} 
Variabel & Mean & SD & SE & p-value & $\mathrm{n}$ \\
\cline { 1 - 4 } Pengetahuan & manajemen hipertensi & & \\
Sebelum & 15,40 & 2,966 & 1,327 & 0,31 & 5 \\
Sesudah & 30,00 & 5,477 & 2,449 & &
\end{tabular}

Dari tabel 13 di atas dapat dilihat dengan nilai p-value $0,031 \quad(<0,05)$ maka dapat disimpulkan bahwa ada perbedaan skor mean 
Pengetahuan manajemen hipertensi sebelum dengan setelah diintervensi, berarti SAK efektif (NIC: Pengajaran proses penyakit: Hipertensi efektif meningkatkan pengetahuan manajemen hipertensi).

\section{NOC Bantuan Perawatan diri Mandi terhadap Perawatan diri: Mandi}

Tabel 14. Perbedaan Mean Skor NOC Perawatan diri Mandi Sebelum dan Setelah Intervensi

\begin{tabular}{lccccc}
\hline \multicolumn{1}{c}{ Variabel } & Mean & SD & SE & $p$-value & N \\
\hline \multicolumn{2}{l}{ Perawatan diri: mandi } & & & & \\
Sebelum & 20,00 & 3,162 & 1,000 & 0,33 & 10 \\
Sesudah & 30,70 & 2,111 & 0,667 & & \\
\hline
\end{tabular}

Dari tabel 14 di atas dapat dilihat dengan nilai $p$-value $0,033 \quad(<0,05)$ maka dapat disimpulkan bahwa ada perbedaan skor mean perawatan diri: mandi sebelum dengan setelah diintervensi, berarti SAK efektif (NIC: Bantuan perawatan diri: mandi efektif meningkatkan perawatan diri mandi).

\section{NOC Bantuan Perawatan Diri: Berpakaian terhadap Perawatan Diri: Berpakaian}

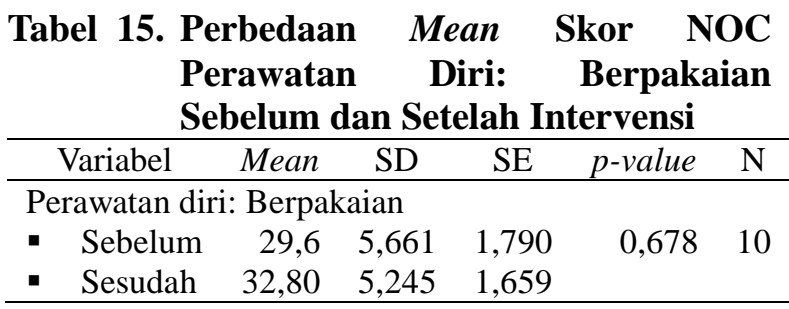

Dari tabel 15 di atas dapat dilihat dengan nilai $p$-value $0,678 \quad(<0,05)$ maka dapat disimpulkan bahwa tidak ada perbedaan skor mean perawatan diri: mandi sebelum dengan setelah diintervensi, berarti SAK tidak efektif (NIC: Bantuan Perawatan diri Berpakaian tidak efektif meningkatkan perawatan diri berpakaian).

\section{NOC Bantuan Perawatan diri: Makan terhadap Perawatan diri: Makan}

Tabel 16. Perbedaan Mean Skor NOC Perawatan diri: Makan Sebelum dan Setelah Intervensi

\begin{tabular}{|c|c|c|c|c|c|}
\hline Variabel & Mean & SD & SE & $p$-value & $\mathrm{N}$ \\
\hline \multicolumn{6}{|c|}{ Perawatan diri: Makan } \\
\hline - Sebelum & 19,70 & 3,234 & 1,023 & 0,002 & 10 \\
\hline Sesudah & 30,70 & 2,111 & 0,667 & & \\
\hline
\end{tabular}

Dari tabel 16 di atas dapat dilihat dengan nilai $p$-value $0,002 \quad(<0,05)$ maka dapat disimpulkan bahwa ada perbedaan skor mean perawatan diri: makan sebelum dengan setelah diintervensi, berarti SAK efektif (NIC: Bantuan Perawatan diri: makan efektif meningkatkan perawatan diri: makan).

\section{PEMBAHASAN}

\section{Aplikasi Nursing Intervention Classification (NIC)}

Hasil penerapan Nursing Intervention Classification (NIC) menunjukkan terdapat 16 dari 20 NIC yang diterapkan pada pasien, semua NIC yang dicobakan efektif terhadap perubahan (positif) skor NOC.

Banyak hal yang menjadi pertimbangan untuk mengaplikasikan NIC dalam perawatan pasien, tujuan yang ingin dicapai (outcome), karakter diagnosa keperawatan (tanda dan gejala yang dominan), pemahaman perawat tentang NIC yang dipilih, biaya dan waktu, penerimaan pasien dan keluarga, kemampuan keterampilan psikomotor dan interpersonal perawat (Nurjannah, 2010).

Intervensi penurunan kecemasan, pemberian analgesik dan bantuan mengontrol nyeri adalah intervensi yang juga sangat dibutuhkan pada pasien pre operasi, Beberapa penelitian terdahulu menyatakan Intervensi keperawatan yang spesifik diperlukan pada pasien perioperatif. Keberhasilan tujuan keperawatan yang efektif berhubungan dengan keberhasilan manajemen nyeri. Intervensi keperawatan melibatkan pasien, pengkajian keperawatan tepat yang dilakukan perawat, kemampuan manajemen, multidisiplin, pendidikan kesehatan, dan strategi manajemen nyeri (Bucknall, Manias, \& Botti, 2001).

Menurut Gilmour D (2005) Nyeri dapat menyebabkan pasien khawatir, distress, dan gelisah. Analgesik dapat diberikan dengan berbagai rute. Perawat harus memiliki keahlian untuk memberikan analgesic. Pengkajian terhadap nyeri diperlukan untuk memonitor efektivitas intervensi pengurangan nyeri. Jika nyeri dapat dikontrol, selanjutnya pasien akan mudah melakukan mobilisasi, dan melakukan latihan napas dalam dan batuk efektif. Pasien akan merasakan kenyamanan dan cenderung tidak gelisah.

Intervensi keperawatan utama pada ibu dengan post $\mathrm{SC}$ adalah manajemen nyeri. Nyeri post SC yang tidak teratasi dapat diidentifikasi sebagai komplikasi yang dapat meningkatkan mual muntah post operasi dan menunda 
penyembuhan. (Watt-Watson, Chung, Chan, \& McGillion, 2004 dalam Giligan).

Nyeri post SC dapat memperparah kondisi infeksi sehingga menunda proses penyembuhan. Pemberian analgesic dapat direncanakan sejak awal untuk mengatasi nyeri post operasi. Persepsi pasien terhadap nyeri dapat dikurangi jika pasien diinformasikan sejak awal (Avidan et al, 2003; Hatfield and Tronson, 2001; Starritt, 200b dalam Gilmour, 2005).

Pencegahan infeksi harus mengikuti protokol/ SOP yang berlaku, pengetahuan, dan skill untuk beradaptasi dengan suasana perioperatif. Intervensi pembedahan menyebabkan kerusakan kulit akibat insersi instrument dan masuknya benda asing ke dalam jaringan, sehingga pasien mengalami risiko infeksi. Pencegahan infeksi terdiri dari banyak komponen, yang pada akhirnya akan bertujuan mencegah risiko infeksi pada pasien akibat respon stress terhadap pembedahan (Gilmour, 2005).

\section{Aplikasi Nursing Outcome Classification (NOC)}

Penilaian NOC hanya dilakukan pada pasien yang mendapatkan $>80 \%$ intervensi dengan NIC, hal ini untuk menunjukkan bahwa perbedaan NOC sebelum dan setelah intervensi terjadi karena dilakukannya intervensi.

Menurut Moorhead, Johnson dan Mass (2004) faktor yang perlu dipertimbangkan dalam pemilihan NOC adalah: tipe kondisi kesehatan pasien: membutuhkan rujukan tenaga profesional, masalah interdisipliner dan diagnosa keperawatan, batasan karakteristik, etiologi dan faktor resiko, karakter pasien, pilihan pasien dan potensial penanganan.

Kondisi masalah kesehatan menyebabkan perawat perlu melakukan rujukan pada tenaga profesional lainnya, jika kondisi kesehatan pasien berada pada kategori ini maka tanggung jawab utama untuk menentukan outcome yang diinginkan biasa berada pada tanggung jawab tim.

Masalah interdisipliner yang menyebabkan perawat perlu melakukan kolaborasi dengan penyedia pelayanan kesehatan lain. Jika pasien mengalami ini maka perawat dan petugas kesehatan lain perlu bekerja bersama untuk mengidentifikasi outcome yang diharapkan akan dicapai pasien.

Diagnosa Keperawatan, Jika pasien mengalami masalah ini maka perawat mempunyai tanggung jawab utama untuk menentukan outcome terkait dengan diagnosa keperawatan yang muncul pada pasien, pada saat memilih outcome yang tepat untuk pasien, perawat perlu mempertimbangkan definisi dari diagnosa keperawatan, batasan karakteristik dan faktor risiko yang berhubungan atau faktor risiko untuk diagnosa keperawatan.

Karakter pasien juga menjadi pertimbangan dalam menentuka NOC, menurut Moorhead, Johnson, Mass (2004) karakter pasien meliputi: karakter personal (faktor demografi : usia, gender, ras, etnik, pendidikan), faktor psikologi/kognitif meliputi kondisi emosional: depresi/cemas, konsentrasi, memori, memproses informasi (Harriet H. Werley, N. M. 1986)

Kondisi keparahan penyakit mempunyai pengaruh yang kuat bagi pemilihan NOC, selain itu status fungsi pasien juga akan mempengaruhi bagaimana memilih NOC. Pemilihan NOC juga perlu mempertimbangkan ketersediaan sumber daya bagi pasien yang akan mempengaruhi penyembuhan dan patient outcome Beberapa sumber daya tersebut berupa keuangan, sosial, keluarga, sumber daya kesehatan yang mempengaruhi gaya hidup dan kemampuan mengakses atau ketersediaan perawatan kesehatan. Ketersediaan intervensi dan potensial intervensi merupakan dua hal lain yang perlu dipertimbangkan dalam memilih outcome.

\section{SIMPULAN}

Berdasarkan uji t teridentifikasi 16 Standar Asuhan Keperawatan yang efektif di Ruang Kebidanan.

\section{SARAN}

1. Metode 6 steps Reasoning Diagnosis dan ICRM direkomendasikan untuk digunakan dalam penentuan Standar Asuhan Keperawatan di ruang rawat terutama ruang kebidanan.

2. Ruang Kebidanan dapat menggunakan Standar Asuhan Keperawatan yang dinyatakan efektif digunakan pada asuhan keperawatan pada 6 kasus terbesar di ruang kebidanan. 


\section{DAFTAR PUSTAKA}

Bucknall, Manias, \& Botti., 200. International Journal On Nursing Practice: Acute Pain Management: Implications of Scientific Evidence for Nursing Practice in The Postoperative Context. (Diakses 14 Maret 2016).

Bulechek G, M. B. 2013. Nursing Intervention Classification. Philadephia: Mosby Elsevier.

Clark J, \&. L. 1992. Nursing's next advance: An internal classification for nursing practice. International Nursing Review, 39 (4), 109-111, 128.

Gilmour, D. 2005. Perioperative Care. http://www.us.elsevierhealth.com (Diakses pada 9 November 2015).

Moorhoed, S. J., at all 2013. Nursing Outcome Classifation (NOC). Philadephia: Elseiver.
Nurjannah, I. 2010. Proses Keperawatan: NANDA, NOC \& NIC. Yogyakarta: MocoMedia.

Nurjannah, I. 2013. Clinical reasoning model for NOC and NIC application. School of Nursing Faculty of Medicine Universitas Gadja Mada. http://keperawatan.ugm.ac.id (Diakses pada 10 Februari 2016).

Perry \& Potter. 2016. Fundamental of Nursing $9^{\text {th }}$ Edition. USA: Elseiver.

Shelvie, R. A.H. 2012. Standar Asuhan Keperawatan. http://www.scribd.com/ doc/BukuStandarAsuhanKeperawatan

Suarni L, Nurjannah I, Apriyani H. 2015. Nursing and Collaborative Diagnoses on Perioperative Patients with and without Using Six Steps of Diagnostic Reasoning Methods. International Journal of Research in Medical Sciences, 3(12), S97-S103. 